\title{
Serum Hepatitis Antigen (SH) Carrier State: Relation to ABO Blood Groups
}

\author{
W. SZMUNESS, A. M. PRINCE, CH. E. CHERUBIN
}

British Medical fournal, 1971, 2, 198-199

\section{Summary}

In a comparison of 347 chronic carriers of the $\mathrm{SH}$ antigen and 8,864 controls with respect to $A B O$ and $R h$ blood group distribution no significant differences have been detected.

\section{Introduction}

Lewkonia and Finn (1969) reported that a significant excess of blood group $\mathrm{O}$ was found among patients and staff members of a Liverpool haemodialysis unit involved in a severe outbreak ( 45 cases) of serum hepatitis. They also found that the more severe cases were almost exclusively of group $O$, and suggested that the $\mathrm{ABO}$ factor may be important in the genesis of serum hepatitis. Similar data, though statistically not significant, were recently reported from Czechoslovakia in a series of 440 patients with a past history of viral hepatitis (Vesely, 1969). A reverse relationship, an excess of blood group $\mathrm{A}$ and deficiency of group $\mathrm{O}$, was described by Zuckerman and McDonald (1963) during an epidemic of probable infectious hepatitis in the British Air Force (378 cases).

Since an association between blood groups and susceptibility to serum hepatitis would be of great theoretical and practical interest, we have evaluated this question by comparing the blood group distribution in carriers of the SH antigen (Australia) and appropriately matched controls.

\section{Subjects}

ABO blood groups were determined and compared in the following four groups.

Group 1 consisted of 177 volunteer blood donors, mostly Caucasians, from the New York Blood Center who were found to carry the SH antigen; SH antigen was detected by routine screening of donor blood during 1969-70. Among those donors who have been followed with serial specimens, $95 \%$ were found to be persistent chronic carriers of the antigen. About $25 \%$ of the carriers showed serum aspartate aminotransferase (S.G.P.T.) values of more than 60 units, suggesting the presence of chronic anicteric hepatitis (Prince and Szmuness, unpublished data)

Group 2 consisted of 7,919 volunteer blood donors, mostly Caucasians, who donated blood at the New York Blood Center during two randomly selected weeks during 1969-70 and in whom SH antigen was not detected.

Laboratory of Virology, the New York Blood Center, New York, N.Y. W. SZMUNESS, M.D., Associate Investigator

Department of Pathology, The New York Hospital, Cornell Medical Center, New York, N.Y.

A. M. PRINCE, M.D., Clinical Associate Professor

Columbia University School of Public Health, New York, N.Y. Ch. E. CHERUBIN, M.D., Harlem Hospital Epidemologist
Group 3 consisted of 170 mentally retarded patients who were carriers of the $\mathrm{SH}$ antigen- 52 were detected during a study at the Suffolk State School, New York (Szmuness et al., 1970) and 118 during a study at the Wassaic State School, New York (Szmuness and Prince, 1970). All of these patients were long-term chronic antigen carriers, and about one-half showed biochemical signs of chronic active hepatitis.

Group 4 consisted of 945 mentally retarded residents of the Wassaic State School in whom SH antigen was not detected. This sample, which had been drawn for other study purposes, was representative of the entire school population and was matched with the patients in group 3 according to race, sex, mental diagnosis, and I.Q. In both groups $12 \%$ of patients had a past history of overt viral hepatitis. Of these residents $97 \%$ showed S.G.P.T. values below 30 units.

Sera were tested for SH antigen by both the Ouchterlony gel diffusion (Prince, 1968) and the high-voltage immunoelectro-osmophoresis (Prince and Burke, 1970) techniques.

\section{Results}

In both the donor series and the mentally retarded series the $\mathrm{ABO}$ blood distribution was exactly or almost exactly the same in carriers of the $\mathrm{SH}$ antigen and in non-carriers (Table I). No difference was found in the distribution of $\mathrm{Rh}$-negative donors. The relatively small differences in distribution in the less common $\mathrm{B}$ and $\mathrm{AB}$ blood groups were statistically not significant $(P>0.05)$.

If the entire sample is divided into smaller groups and the relatively more homogenous subsamples are analysed certain differences in ABO group distribution can be found. As may be seen in Table II, in mentally retarded Negro $\mathrm{SH}$ antigen carriers there is an apparent excess of group $A$ and deficiency of group $\mathrm{O}$; and in the carriers with Down's syndrome an excess of group $\mathrm{O}$, and so forth. Even though some of these differences are on the borderline of significance, the numerators are rather small and the rates, therefore, may be apt to random fluctuations. As a rule, the smaller the subsamples the more frequently were various differences in blood group distribution, in one or the other direction, observed and vice versa.

\section{Discussion}

The above data differ essentially from reports suggesting an association between acute viral hepatitis and ABO blood groups. Our data indicate that when sufficiently large samples are tested there is no significant difference in the ABO blood group distribution among carriers of the $\mathrm{SH}$ antigen and noncarriers. Since SH antigenaemia may be thought to be indicative of the serum hepatitis virus carrier state, it can be assumed that at least the development of this form of viral hepatitis is not associated with any particular blood group. The results of this study cannot, of course, be extrapolated to other clinical or aetiological forms of viral hepatitis. It should, 
TABLE I-Distribution of ABO Blood Groups in Chronic Carriers and Non-carriers of the SH Antigen

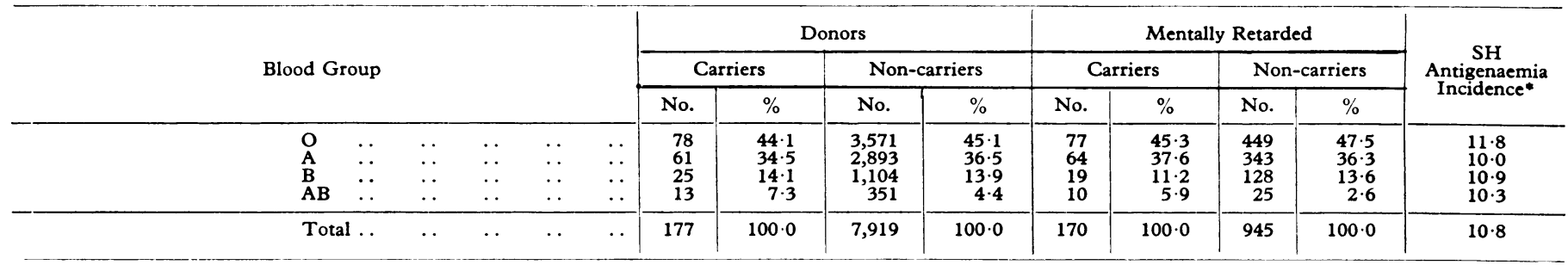

-Wassaic State School only.

TABLE II-Distribution of ABO Blood Groups in Mentally Retarded Patients in Relation to Race and Mental Diagnosis

\begin{tabular}{|c|c|c|c|c|c|c|c|c|c|c|c|c|c|c|c|c|c|c|}
\hline \multirow{2}{*}{\multicolumn{3}{|c|}{ Blood Group }} & \multicolumn{4}{|c|}{ Caucasians } & \multicolumn{4}{|c|}{ Negroes } & \multicolumn{4}{|c|}{ Mongols } & \multicolumn{4}{|c|}{ Non-mongols } \\
\hline & & & \multicolumn{2}{|c|}{ Carriers } & \multicolumn{2}{|c|}{ Non-carriers } & \multicolumn{2}{|c|}{ Carriers } & \multicolumn{2}{|c|}{ Non-carriers } & \multicolumn{2}{|c|}{ Carriers } & \multicolumn{2}{|c|}{ Non-carriers } & \multicolumn{2}{|c|}{ Carriers } & \multicolumn{2}{|c|}{ Non-carriers } \\
\hline & & & No. & $\%$ & No. & $\%$ & No. & $\%$ & No. & $\%$ & No. & $\%$ & No. & $\%$ & No. & $\%$ & No. & $\%$ \\
\hline $\begin{array}{l}\mathrm{O} \\
\mathrm{A} \\
\mathrm{B} \\
\mathrm{AB}\end{array}$ & $\begin{array}{l}\cdots \\
\cdots \\
\cdots\end{array}$ & $\begin{array}{l}. . \\
\cdots \\
\cdots\end{array}$ & $\begin{array}{r}68 \\
51 \\
15 \\
8\end{array}$ & $\begin{array}{r}47.9 \\
35.9 \\
10.6 \\
5.6 \\
\end{array}$ & $\begin{array}{r}369 \\
306 \\
101 \\
24 \\
\end{array}$ & $\begin{array}{r}46 \cdot 1 \\
38 \cdot 3 \\
12 \cdot 6 \\
3 \cdot 0 \\
\end{array}$ & $\begin{array}{r}9 \\
13 \\
4 \\
2 \\
\end{array}$ & $\begin{array}{r}32 \cdot 1 \\
46 \cdot 5 \\
14 \cdot 3 \\
7 \cdot 1 \\
\end{array}$ & $\begin{array}{r}80 \\
37 \\
27 \\
1 \\
\end{array}$ & $\begin{array}{r}55 \cdot 2 \\
25.5 \\
18.6 \\
0.7 \\
\end{array}$ & $\begin{array}{r}45 \\
39 \\
7 \\
6 \\
\end{array}$ & $\begin{array}{r}46 \cdot 4 \\
40 \cdot 2 \\
7 \cdot 2 \\
6 \cdot 2 \\
\end{array}$ & $\begin{array}{r}67 \\
71 \\
25 \\
4\end{array}$ & $\begin{array}{r}40.1 \\
42.5 \\
15.0 \\
2.4 \\
\end{array}$ & $\begin{array}{r}32 \\
25 \\
12 \\
4 \\
\end{array}$ & $\begin{array}{r}43 \cdot 8 \\
34.3 \\
16.4 \\
5.5 \\
\end{array}$ & $\begin{array}{r}382 \\
272 \\
103 \\
21 \\
\end{array}$ & $\begin{array}{r}49 \cdot 1 \\
35 \cdot 0 \\
13 \cdot 2 \\
2 \cdot 7 \\
\end{array}$ \\
\hline \multicolumn{2}{|c|}{ Total .. } & .. & 142 & $100 \cdot 0$ & 800 & $100 \cdot 0$ & 28 & $100 \cdot 0$ & 145 & $100 \cdot 0$ & 97 & $100 \cdot 0$ & 167 & $100 \cdot 0$ & 73 & $100 \cdot 0$ & 778 & $100 \cdot 0$ \\
\hline
\end{tabular}

however, be emphasized that an association with blood groups was not found in posttransfusion hepatitis studies carried out with large patient samples and adequate controls in the U.S.A. (189 patients) (Allen and Sayman, 1962), Japan (587 patients) (Shimada et al., 1965), and Poland (70 patients) (Szmuness et al., 1966). Thus it seems unlikely that serum hepatitis could have been a selective factor determining the distribution of $\mathrm{ABO}$ or $\mathrm{Rh}$ antigens in populations, or that these blood groups are associated with susceptibility to either acute or chronic forms of serum hepatitis virus infections.

This study was supported by NIH Grants AI 09516 and HE 09011 and a grant-in-aid from the Strasburger Foundation. A.M.P. is the recipient of a Career Scientist Award of the Health Research Council of the City of New York under Contract I-533. Requests for reprints should be addressed to W.S., The New York Blood Center, 310 East 67th Street, New York, N.Y. 10021.

\section{References}

Allen, J. G., and Sayman, W. A. (1962). Fournal of the American Medical Association, 189, 1079.

Lewkonia, R. M., and Finn, R. (1969). British Medical fournal, 3, 268.

Prince, A. M. (1968). Proceedings of the National Academy of Sciences of the United States of America, 60, 814 .

Prince, A. M., and Burke, K. (1970). Science, 169, 593.

Shimada, N., et al. (1965). In Proceedings of the 10th Congress of the International Society of Blood Transfusion, p. 1066.

Szmuness, W., Gawronowa, M., and Horoch Cz. (1966). Epidemiological Reviews, 20, 201.

Szmuness, W., Pick, R., and Prince, A. M. (1970). American fournal of Epidemiology, 92, 51 .

Szmuness, W., and Prince, A. M. (1970). Intra-Institutional Spread of Serum Hepatitis Specific Antigen. Abstract of the American Public Serum Hepatitis Specific Antigen. Abstract of the American
Health Association Annual Meeting, Houston, Texas, October.

Vesely, K. T. (1969). Vnitřni Lékałstvi, 15, 1089.

Zuckerman, A. J., and McDonald, J. C. (1963). British Medical fournal, 2, 537 .

\title{
Further Observations on the Effect of Synthetic Thyrotrophin-releasing Hormone in Man
}

\author{
B. J. ORMSTON, J. R. KILBORN, R. GARRY, JACQUELINE AMOS, REGINALD HALL
}

British Medical fournal, 1971, 2, 199-202

\section{Summary}

Synthetic thyrotrophin-releasing hormone (TRH) given intravenously in doses of $50 \mu \mathrm{g}$ or more causes a significant rise in serum thyroid-stimulating hormone (TSH) levels but has no effect on serum growth hormone, plasma luteinizing hor-

\footnotetext{
University of Newcastle upon Tyne and Royal Victoria Infirmary, Newcastle upon Tyne NE1 4LP

B. J. ORMSTON, M.B., B.S., Research Fellow in Endocrinology

J. R. KILBORN, M.B., PH.D., Research Officer in Medicine

R. GARRY, M.B., B.S., Senior House Officer in Medicine

JACQUELINE AMOS, Chief Technician

REGINALD HALL, M.D., F.R.C.P., Professor of Medicine
}

mone, or plasma 11-hydroxycorticosteroids under carefully controlled basal conditions.

The peak TSH response to intravenous TRH occurs at 20 minutes. The mild and transient side effects, which occur only after intravenous TRH, include nausea, a flushing sensation, a desire to micturate, a peculiar taste, and tightness in the chest. There is considerable variability in response to a given dose of TRH in the same subject on different occasions and in different subjects. Oral administration of TRH in doses of $1 \mathrm{mg}$ and above causes a rise in serum TSH, maximal at two hours, a consistent response being obtained at doses of $20 \mathrm{mg}$ and above. A rise in serum protein-bound iodine (P.B.I.) follows that of TSH, a consistent response being observed at $40-\mathrm{mg}$ doses of TRH orally. Measurements of serum TSH after intravenous administration of TRH or of serum TSH or serum P.B.I. after oral TRH should prove useful tests of pituitary TSH reserve. 